\title{
Heart Septum
}

National Cancer Institute

\section{Source}

National Cancer Institute. Heart Septum. NCI Thesaurus. Code C49485.

The tissue in the heart that separates the two atria (atrial septum) and the two ventricles (ventricular septum). 